\title{
False positive complement fixation tests with respiratory virus preparations in bird fanciers with allergic alveolitis
}

\author{
A. J. NEWMAN TAYLOR ${ }^{1}$, P. TAYLOR ${ }^{2}$, D. H. BRYANT ${ }^{1}$, JOAN L. LONGBOTTOM ${ }^{1}$, \\ AND J. PEPYS ${ }^{1}$ \\ From the Department of Clinical Immunology ${ }^{1}$, Cardiothoracic Institute, and the Department of \\ Virology ${ }^{2}$, Brompton Hospital, London SW3 6HP, UK
}

Newman Taylor, A. J., Taylor, P., Bryant, D. H., Longbottom, Joan L., and Pepys, J. (1977). Thorax, 32, 563-566. False positive complement fixation tests with respiratory virus preparations in bird fanciers with allergic alveolitis. False positive raised complement fixation titres to egg-grown virus preparations were found in six pigeon fanciers suffering from extrinsic allergic alveolitis but not in six similar budgerigar fanciers. The raised titres in the pigeon fanciers fell fourfold over a short interval in the absence of avian exposure and were attributable to antibodies directed against antigens from hen's egg in which the test virus preparations were grown. Such antigens were shown to be present in the virus preparations. In view of the clinical similarities between influenza and acute extrinsic allergic alveolitis, it is essential that a diagnosis of influenza in bird fanciers is not based on either a single raised titre or a fourfold fall in complement fixation titre without appropriate control tests with avian antigens.

The development of extrinsic allergic alveolitis in bird fanciers, particularly in those exposed to pigeons and budgerigars, is commonly associated with the production of precipitating antibodies to a wide range of avian antigens (Barboriak et al., 1965; Faux et al., 1971a; Faux et al., 1971b). A study of complement fixing activity to egg-grown respiratory virus preparations of the sera of bird fanciers with allergic alveolitis was initiated by the observation in a pigeon fancier with acute extrinsic allergic alveolitis that there were raised complement fixation titres in Influenza $A$ and $B$ viruses together with comparable titres to a preparation of chorioallantoic membrane in which the test virus preparations were grown. These titres fell fourfold over a period of one month during which there was no avian exposure.

\section{Material and methods}

PATIENTS' SERA

Paired sera were obtained from six pigeon fanciers and six budgerigar fanciers, both groups having extrinsic allergic alveolitis. This diagnosis was based on the clinical, radiological, and physiological findings, together with positive avian pre- cipitin tests. The initial serum sample was obtained either at the time of (or within two to three weeks of) avian exposure. The second specimen was obtained from the pigeon fanciers three weeks or more later, and between one week and one month later in the budgerigar fanciers. Two of the pigeon fanciers and one of the budgerigar fanciers continued to be exposed to their birds. In the remainder there was no further avian exposure after the first sample had been taken. Sera from five patients with a clinical and serological diagnosis of influenza, but no known avian exposure, were used as controls.

\section{Methods}

Complement fixation tests were made on all the sera with the following eight virus test and other antigens: Influenza A, B, and C, Sendai, Psittacosis, Coxiella burneti, chorioallantoic membrane, and yolk sac of chicken egg, obtained from the Standards Laboratory, Colindale. A microtitre adaptation of the method of Bradstreet and Taylor (1962) was employed. Haemagglutination-inhibition tests were made on selected sera after treatment with receptor-destroying enzyme to remove 
non-specific inhibitors. The antigens used in the haemagglutination tests, Influenza A2, 42/72, and A2 Port Chalmers 1/73, were obtained from Flow Laboratories, Scotland. The haemagglutinationinhibition method was similar to that of Hoskins (1967) using a PBSA-bovine albumin diluent.

A further complement fixation antigen was prepared using a Rhesus monkey kidney cell culture adapted strain of Influenza A virus which had been passaged several times before preparation of the antigen by treatment of the supernatant fluid with guinea-pig erythrocytes to remove haemagglutinins.

Immunoelectrophoretic tests (Pepys and Jenkins, 1965) were made with the preparation of Influenza $A$ and $B$ viruses and of the chicken egg chorioallantoic membrane extract against an egg white antiserum, and against the bird fanciers' sera. The sera of the influenza patients were used as controls.

\section{Results}

COMPLEMENT FIXATION AND HAEMAGGLUTINATIONINHIBITION TESTS IN PIGEON FANCIERS

Egg-grown Influenza $A$ and $B$ viruses and chicken egg chorioallantoic membrane

Raised complement fixation titres to both Influenza $A$ and $B$ viruses and to the chorioallantoic membrane extracts were found in the initial sample of all six pigeon fanciers (Table 1). Except for Influenza A in P4, a fourfold fall in titre was observed in the second serum sample in the four pigeon fanciers (P1 to P4) who had no further exposure to their pigeons, whereas there was no significant fall in the two pigeon fanciers with

Table 1 Complement fixation titres to Influenza $A$ and $B$ viruses and to hen egg chorioallantoic membrane $(C A M)$ and haemagglutination inhibition titres (HAI) to Influenza A2 Port Chalmers and to Influenza $A 2$ England in paired sera from six pigeon fanciers

\begin{tabular}{|c|c|c|c|c|c|c|}
\hline & \multirow{2}{*}{$\begin{array}{l}\text { Period } \\
\text { since } \\
\text { pigeon } \\
\text { exposure }\end{array}$} & \multicolumn{2}{|l|}{ CFTs } & \multicolumn{2}{|l|}{$\boldsymbol{H A I}$} & \multirow[b]{2}{*}{$C A M$} \\
\hline & & $F l u^{\prime} A$ & $F l u^{\prime} B$ & $\begin{array}{l}F l u^{\prime} \\
A_{2} P C\end{array}$ & $\begin{array}{l}F l u^{\prime} \\
A_{2} E\end{array}$ & \\
\hline \multirow[t]{2}{*}{ P1 } & 4 days & 320 & 320 & 40 & 10 & 320 \\
\hline & 5 weeks & 80 & 80 & 20 & $<5$ & 80 \\
\hline \multirow[t]{2}{*}{ P2 } & 2 weeks & 160 & 160 & 20 & $<5$ & 160 \\
\hline & 5 weeks & 40 & 40 & 20 & $<5$ & 40 \\
\hline \multirow[t]{2}{*}{ P3 } & Exposed & 320 & 160 & & & 160 \\
\hline & 3 weeks & 80 & 40 & & & 40 \\
\hline \multirow[t]{2}{*}{ P4 } & 3 weeks & 80 & 160 & 160 & $<10$ & 160 \\
\hline & 5 months & 80 & 40 & 320 & $<10$ & 40 \\
\hline \multirow[t]{2}{*}{ P5 } & Exposed & 160 & 160 & 40 & 5 & 320 \\
\hline & (2/12 later) & 160 & 160 & 20 & 5 & 320 \\
\hline \multirow[t]{2}{*}{ P6 } & Exposed & 320 & 320 & $<10$ & 40 & 320 \\
\hline & (4/12 later) & 160 & 160 & $<10$ & 20 & 160 \\
\hline
\end{tabular}

continued exposure. Haemagglutination-inhibition $\stackrel{\vec{F}}{\stackrel{\vec{S}}{\rightarrow}}$ titres to Influenza A2 England and A2 Port Chalmers test preparations showed no significant $\overline{ }$ change in titre between the two serum samples.

\section{Monkey kidney adapted Influenza $A$ virus}

Complement fixation tests with a monkey kidney cell culture of adapted Influenza A virus were? made on paired serum samples with raised titres $\vec{\omega}$ to the egg-grown viruses from two of the pigeon $\stackrel{\circ}{\circ}$ fanciers and compared with the five control influ- $\overrightarrow{\vec{x}}$ enza patients (Table 2). The latter had significantly $\omega$ raised titres to both egg and monkey kidney grown or Influenza $A$ virus, whereas the pigeon fanciers had $i r$ raised titres only to the egg-grown virus. The $\mathrm{E}$ influenza patients had no rise in titre to the egg- $\frac{\text { 의 }}{5}$ grown Influenza B virus or to the chicken egg chorioallantoic membrane.

Table 2 Complement fixation titres to egg-grown Influenza $A$ and $B$ viruses, to hen egg chorioallantoic $\vec{v}$ membrane, and to monkey kidney adapted Influenza 그 $A$ virus compared in two pigeon fanciers and five patients with influenza

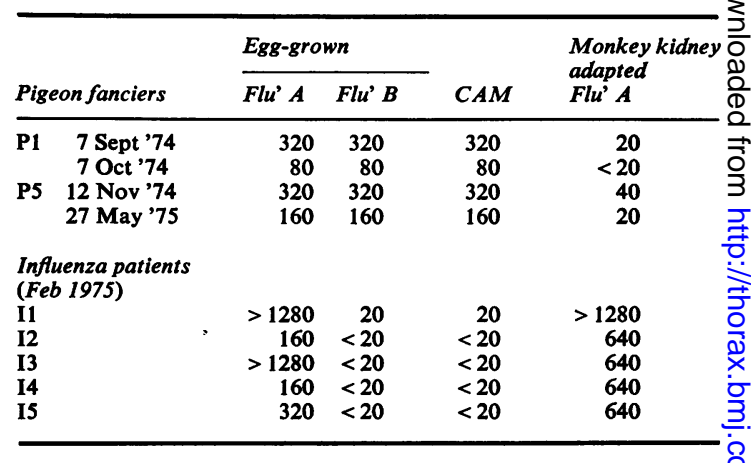

Other egg-grown respiratory viruses
Table 3 shows complement fixation tests with Influenza $C$ and Parainfluenza (Sendai) viruses harvested from allantoic fluid and Psittacosis and $C$. burneti grown in yolk sac. Two of the first four or patients who had no avian exposure after the $N$ initial serum sample had raised titres in the first sample to Influenza $C$ and Sendai virus prepara- 0 tions, with a fourfold fall in the second sample. Of the two continuously exposed pigeon fanciers, $\frac{}{\Phi}$ one had raised complement fixation titres to both $\stackrel{\leftrightarrow}{+}$ virus preparations in both samples. Only one 0 pigeon fancier (P4) had comparable raised com- 0 plement fixation titres to Psittacosis and C. burnet $i \stackrel{\curvearrowright}{\AA}$ preparations and yolk sac extract in the first $\mathbb{\Phi}$ sample, with a fourfold fall to all three prepara- $\frac{\circ}{\sigma}$ tions in the second serum sample. 
Table 3 Complement fixation titres to Influenza $C$ and Parainfluenza (Sendai) viruses and to Psittacosis C. burneti, and hen egg yolk sac

\begin{tabular}{|c|c|c|c|c|c|}
\hline & Flu' C & $\begin{array}{l}\text { Para- } \\
\text { influenza } \\
\text { (Sendai) }\end{array}$ & Psittacosis & $Q$ fever & Yolk sac \\
\hline P1 & $\begin{array}{l}20 \\
20\end{array}$ & $\begin{array}{l}40 \\
40\end{array}$ & $\begin{array}{l}<20 \\
<20\end{array}$ & $\begin{array}{l}<20 \\
<20\end{array}$ & $\begin{array}{l}<20 \\
<20\end{array}$ \\
\hline P2 & $\begin{array}{r}320 \\
40\end{array}$ & $\begin{array}{r}320 \\
40\end{array}$ & $\begin{array}{l}<20 \\
<20\end{array}$ & $\begin{array}{l}<20 \\
<20\end{array}$ & $\begin{array}{l}20 \\
20\end{array}$ \\
\hline P3 & $\begin{array}{r}160 \\
40\end{array}$ & $\begin{array}{l}80 \\
40\end{array}$ & $\begin{array}{r}20 \\
<20\end{array}$ & $\begin{array}{r}20 \\
<20\end{array}$ & $\begin{array}{r}20 \\
<20\end{array}$ \\
\hline P4 & $\begin{array}{r}160 \\
80\end{array}$ & $\begin{array}{r}160 \\
40\end{array}$ & $\begin{array}{r}40 \\
<20\end{array}$ & $\begin{array}{r}40 \\
<20\end{array}$ & $\begin{array}{l}80 \\
20\end{array}$ \\
\hline P5 & $\begin{array}{l}320 \\
320\end{array}$ & $\begin{array}{l}40 \\
40\end{array}$ & $\begin{array}{l}<20 \\
<20\end{array}$ & $\begin{array}{l}<20 \\
<20\end{array}$ & $\begin{array}{l}<20 \\
<20\end{array}$ \\
\hline P6 & $\begin{array}{l}640 \\
640\end{array}$ & $\begin{array}{l}320 \\
320\end{array}$ & $\begin{array}{l}<20 \\
<20\end{array}$ & $\begin{array}{l}<20 \\
<20\end{array}$ & $\begin{array}{l}<20 \\
<20\end{array}$ \\
\hline
\end{tabular}

COMPLEMENT FIXATION TESTS IN BUDGERIGAR FANCIERS

Influenza $A$ and $B$ viruses and chicken egg chorioallantoic membrane

Table 4 shows that, of the six budgerigar fanciers, only two had raised titres (1 in 40) in both samples: to Influenza $A$ and $B$ in $B 1$ and to Influenza $\mathbf{A}$ alone in $\mathbf{B} 3$.

\section{Precipitin analysis of test preparations}

In immunoelectrophoretic tests of the Influenza $A$ and $B$ extracts and of the chorioallantoic membrane extracts against an egg-white antiserum, small quantities of $\alpha$-globulin and pre-albumin and larger quantities of $\beta$-globulin, ovotransferrin, ovomucoid, and egg albumin were demonstrable in both virus and chorioallantoic membrane extracts (Figure). The albumin in the influenza virus extracts migrated more slowly than the albumin in the chorioallantoic membrane. No attempt was made to see whether this may have been due to the preparation of the influenza virus material for serological testing.
Table 4 Complement fixation titres to Influenza $A$ and $B$ viruses and to hen egg chorioallantoic membrane in paired sera from six budgerigar fanciers

\begin{tabular}{|c|c|c|c|c|}
\hline & \multirow{2}{*}{$\begin{array}{l}\text { Period since } \\
\text { budgerigar } \\
\text { exposure }\end{array}$} & \multicolumn{2}{|l|}{ CFTs } & \multirow[b]{2}{*}{$C A M$} \\
\hline & & Flu' $A$ & $F l u^{\prime} B$ & \\
\hline B1 & Exposed & 40 & 40 & 40 \\
\hline B2 & $\begin{array}{l}\text { Exposed } \\
3 \text { days } \\
3 \text { weeks }\end{array}$ & $\begin{array}{l}<20 \\
<20\end{array}$ & $\begin{array}{l}<20 \\
<20 \\
<20\end{array}$ & $\begin{array}{l}20 \\
<20 \\
<20\end{array}$ \\
\hline B3 & $\begin{array}{l}1 \text { day } \\
2 \text { weeks }\end{array}$ & $\begin{array}{l}40 \\
40\end{array}$ & $\begin{array}{l}<20 \\
<20\end{array}$ & $\begin{array}{l}<20 \\
<20\end{array}$ \\
\hline B4 & $\begin{array}{l}1 \text { day } \\
1 \text { month }\end{array}$ & $\begin{array}{l}<20 \\
<20\end{array}$ & $\begin{array}{l}<20 \\
<20\end{array}$ & $\begin{array}{l}<20 \\
<20\end{array}$ \\
\hline B5 & $\begin{array}{l}2 \text { days } \\
3 \text { weeks }\end{array}$ & $\begin{array}{l}<20 \\
<20\end{array}$ & $\begin{array}{l}<20 \\
<20\end{array}$ & $\begin{array}{l}<20 \\
<20\end{array}$ \\
\hline B6 & $\begin{array}{l}\text { Exposed } \\
1 \text { week }\end{array}$ & $\begin{array}{l}<20 \\
<20\end{array}$ & $\begin{array}{l}20 \\
20\end{array}$ & $\begin{array}{l}20 \\
20\end{array}$ \\
\hline
\end{tabular}

Five of the six pigeon fanciers and four of the six budgerigar fanciers had precipitating antibody to egg albumin in the chorioallantoic membrane and influenza virus extracts (Table 5). In addition, one of the pigeon fanciers and one of the budgerigar fanciers had precipitating antibody to the $\beta$-globulin fraction present in both extracts. In none of the influenza patients was precipitating antibody to the virus or chorioallantoic membrane extracts demonstrated.

\section{Discussion}

The finding in a single pigeon fancier of raised complement fixation titres to a wide range of egggrown virus preparations was interpreted by Boyd et al. (1967) as an anamnestic antibody response to virus antigens. We have now shown that the sera of six pigeon fanciers with allergic alveolitis gave raised complement fixation titres in Influenza $A$ and $B$ virus preparations. Three of the pigeon fanciers also had raised titres to Influenza $C$ and Parainfluenza (Sendai) virus preparations, and in

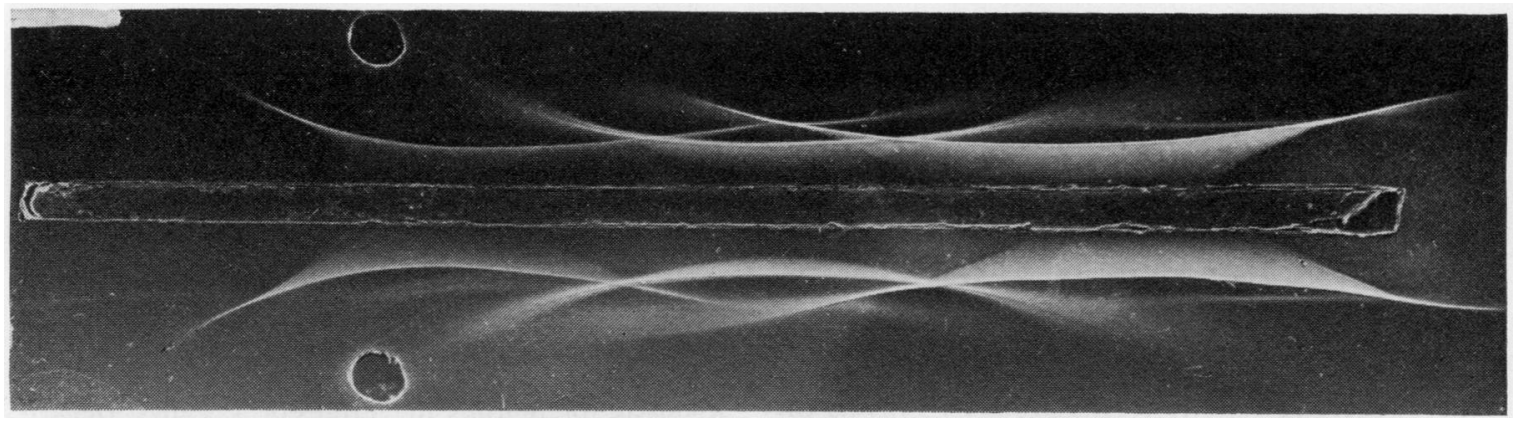

Figure Immunoelectrophoresis of Influenza A virus preparation (above) and of chorioallantoic membrane (below) against egg white antiserum. 
Table 5 Precipitin lines to albumin and to $\beta$ globulin in Influenza A virus and chorioallantoic membrane preparations compared in six pigeon fanciers, six budgerigar fanciers, and five patients with influenza

\begin{tabular}{|c|c|c|c|c|}
\hline & \multicolumn{2}{|c|}{ Influenza $A$} & \multicolumn{2}{|c|}{$\begin{array}{l}\text { Chorioallantoic } \\
\text { membrane }\end{array}$} \\
\hline & $\beta$ globulin & albumin & $\beta$ globulin & albumin \\
\hline P1 & - & + & - & + \\
\hline P2 & + & + & + & t \\
\hline P3 & - & + & - & + \\
\hline P4 & - & + & - & + \\
\hline P5 & & - & - & - \\
\hline P6 & - & + & - & $i$ \\
\hline B1 & 1. & -1 & + & + \\
\hline B2 & - & $\div$ & - & - \\
\hline B3 & - & $\ldots$ & - & + \\
\hline B4 & - & $\div$ & & $\div$ \\
\hline B5 & - & - & - & - \\
\hline B6 & - & - & - & - \\
\hline I1 & -. & - & - & - \\
\hline 12 & - & - & - & - \\
\hline 13 & - & - & - & - \\
\hline 14 & - & - & - & - \\
\hline 15 & - & $\ldots$ & - & - \\
\hline
\end{tabular}

only one to preparations of Psittacosis and $C$. burneti. The fourfold fall in titre which occurred over a short period of avoidance of avian exposure was like that seen in recent viral infections.

The complement fixing activity of the sera was directed against antigens derived from the hen's egg in which the viruses were grown and not against viral antigens. The complement fixing titres in paired sera to the Influenza A and B viruses grown on hen egg chorioallantoic membrane were associated with comparable titres to an extract of chorioallantoic membrane itself. Haemagglutination-inhibition activity, which depends on antibody to virus coat antigen, showed no changes in tests with the two currently prevalent strains of Influenza A2 virus. Complement fixation titres to monkey kidney cell cultures of adapted Influenza A virus were raised in the five patients with influenza, but not in the pigeon fanciers.

Antigens reacting with egg white antiserum were demonstrated by immunoelectrophoresis in the Influenza $A$ and $B$ virus extracts used for serological testing, and precipitating antibodies to egg white albumin and $\beta$ globulin were found in the serum of five each of the six pigeon and six budgerigar fanciers. Nevertheless, the complement fixation titres to these virus preparations were high in the pigeon fanciers but negative or low in the budgerigar fanciers. This probably reflects the fact that pigeon fanciers tend to be more heavily exmosed to avian antigens in the dry droppings

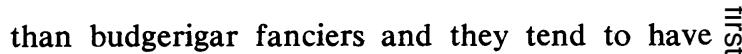
greater amounts of antibody.

The interpretation of viral diagnostic tests in sensitised bird fanciers and particularly in those $\frac{\bar{m}}{\sigma}$ with extrinsic allergic alveolitis must take these $\mathbb{\mathbb { Q }}$ findings into account. There are similarities between influenzal pneumonia and acute extrinsic s allergic alveolitis, such as fever, malaise, myalgia,. and severe pulmonary symptoms of acute onset $\overrightarrow{\vec{\omega}}$ associated with widespread ill-defined, nodular ${ }^{\circ}$ shadowing on the chest radiograph. In bird fan- $\vec{x}$ ciers, a definite diagnosis of influenza virus infec- $\underset{\omega}{\dot{\omega}}$ tion cannot therefore be based, as has been $\stackrel{N}{0}$ suggested, on either a single raised complement or fixation titre (Oswald et al., 1975) or even on the $\mathscr{E}$ more suggestive rapidly falling titres. The presence $\mathrm{O}$ of raised complement fixation titres to two or more other egg-grown viruses suggests that such $O$ elevated titres may be attributable to reactions to avian rather than virus antigens. These observa- $\mathbb{\Phi}^{\circ}$ tions make it desirable that there should be appropriate egg antigen controls in these tests and that $\overrightarrow{0}$ virologists should be informed when sera are sub- 그 mitted for complement fixation tests against egggrown viruses that the subjects have been exposed to avian antigens.

\section{References}

Barboriak, J. J., Sosman, A. J., and Reed, C. E. (1965). Serological studies in pigeon breeder's lung. Journal of Laboratory and Clinical Medicine, 65, 600-604.

Boyd, G., Dick, H. W., Lorimer, A. R., and Morgan, F. (1967). Bird breeder's lung. Scottish Medical Journal, 12, 69-71.

Bradstreet, C. M. P., and Taylor, C. E. D. (1962). Technique of complement fixation test applied to $\bar{\sigma}$ the diagnosis of virus diseases. Monthly Bulletin of the Ministry of Health and Public Laboratory Service, 21, 96-104.

Faux, J. A., Wells, I. D., and Pepys, J. (1971a). Specificity of avian serum proteins in tests against the sera of bird fanciers. Clinical Allergy, 1, 159170.

Faux, J. A., Wide, L., Hargreave, F. E., Longbottom, $\bar{N}$ J. L., and Pepys, J. (1971b). Immunological aspects or of respiratory allergy in budgerigar (Melopsittacus $\mathrm{N}$ undulatus) fanciers. Clinical Allergy, 1, 149-158.

Hoskins, J. M. (1967). Virological Procedures, pp. 241249, Butterworths, London.

Oswald, N. C., Jones, M. C., and Yealland, S. J. (1975). A review of routine tests for respiratory $\mathbb{\&}$ viruses in hospital inpatients. Thorax, 30, 361-366.

Pepys, J., and Jenkins, P. A. (1965). Precipitin T (F.L.H.) test in farmer's lung. Thorax, 20, 21-35.

Requests for reprints to: Professor J. Pepys, Department of Clinical Immunology, Cardiothoracic Institute, Brompton, London SW3 6HP, UK. 